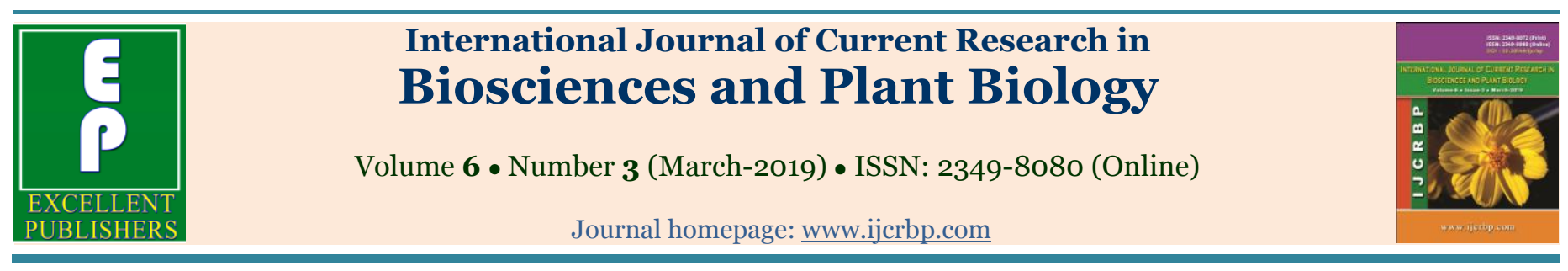

\title{
Supplement to the legumes of Tamil Nadu, India
}

\author{
R. Kottaimuthu', 2* \\ ${ }^{1}$ Department of Botany, Saraswathi Narayanan College, Madurai-625 022, Tamil Nadu, India ${ }^{2}$ Presently at: Department of Botany, \\ Alagappa University, Karaikudi-630003, Tamil Nadu, India \\ ${ }^{*}$ Corresponding author
}

\begin{tabular}{ll}
\hline Article Info & ABSTRACT \\
\hline $\begin{array}{l}\text { Date of Acceptance: } \\
\text { 10 February 2019 }\end{array}$ & $\begin{array}{l}\text { During the literature survey on Legumes of Tamil Nadu for the Ph. D. dissertation of } \\
\text { the author, he has compiled the scattered information from various journals and books. } \\
\text { In order to bring the Legumes of Tamil Nadu more complete, it has been considered } \\
\text { Date of Publication: } \\
\text { o6 March 2019 }\end{array}$ \\
$\begin{array}{l}\text { meaningful to publish the taxonomic account of all additional taxa in the form of a } \\
\text { supplement. This will be very useful to various researchers who were engaged on the } \\
\text { study of legumes of India. A total number of 9o taxa of legumes belonging to 42 genera } \\
\text { are enumerated in this paper. Two new combinations [Senegalia tanjorensis (Ragup., } \\
\text { Thoth. \& A. Mahad.) Kottaim. and Vachellia pseudowightii (Thoth.) Kottaim.] are also } \\
\text { India }\end{array}$ & $\begin{array}{l}\text { proposed in the paper. } \\
\text { Legumes }\end{array}$
\end{tabular}

Literature survey

Supplement

\section{Introduction}

Fabaceae (nom. alt. Leguminosae) is one of the most successful lineages of flowering plants. Next to Asteraceae and Orchidaceae, it is the third largest angiosperm family consisting of about 751 genera and 19,500 species (Lewis et al., 2005). Moreover, it harbours the largest genus of flowering plants, Astragalus L. (Sanderson and Wojciechowski, 1996). Legumes are important components of nearly all terrestrial biomes and forming ecologically important constituents of temperate, Mediterranean, tropical, arid, seasonally dry, rain forest, and savanna ecosystems (Yahara et al., 2013). The family presents amazing morphological and life history diversity, from giant rain forest trees and woody lianas, to desert shrubs, ephemeral herbs, herbaceous twining climbers, aquatics and fire-adapted savanna species (Lewis et al., 2005).

Taxonomic treatment of legumes of India began with Henrich van Rheede (1678-1703), who described and enumerated 63 species belonging to 33 genera in Hortus Indicus Malabaricus (Manilal 2003; Nicolson et al., 1988). Based on this work and other collections from India Linnaeus (1753, 1754) described 72 species of legumes belonging to 20 genera in his species plantarum and Genera Plantarum (Sanjappa, 2001). Thereafter Burman (1768), Lamarck (1786), Willdenow (1802), De Candolle (1825), Taubert (1894) and Wallich (1820), Roxburgh $(1795,1832)$, Wight and Arnott (1834) and Bentham (1843) contributed significantly to Indian legumes. However, the most extensive study on legumes of India was done by 
Baker (1876-1878), who documented 833 species belonging to 132 genera. Among them only 548 species in 120 genera were distributed within the present political boundary of India (Sanjappa, 1992). Sanjappa during 1992 published a checklist of all the known Indian legumes based on literature and specimens available in various herbaria. This checklist not only gives the magnitude of legume diversity in India but also provides baseline data for taxonomic revisions, floristic accounts and monographs (Sanjappa, 2001).

After the publication of "Flora of Tamil Nadu", many legumes are reported from Tamil Nadu either as new to science or as new reports to the state. But, Betty and Ramachandran (2014) have listed only 11 species as an addition to the legumes of Tamil Nadu. During the literature survey on Legumes of Tamil Nadu for the Ph. D. dissertation, the author has compiled the scattered information from various journals and books. Totally 90 taxa of legumes are enumerated with original citation. Moreover, earlier some of the taxa omitted by Vajravelu (1983) are also included in the present communication.

\section{Systematic Enumeration}

Note: The botanical names marked with the following symbols denote: *: New record for India; **: New record for South India or Peninsular India; \#: New record for Tamil Nadu.

*Acacia colei Maslin \& L. A. J. Thomson in Austral. Syst. Bot. 5: 737. 1992; Chakrab. \& V. Maina in J. Econ. Taxon. Bot. 39(1): 194. 2015.

Distribution:-INDIA (Cultivated in Goa, Tamil Nadu \& West Bengal)-A native of Australia.

*Acacia decipiens R. Br. in Ait. f.,Hort. Kew. ed. 3, 5. 463. 1813; Sanjappa, Legumes Ind. 47. 1992.

Distribution:-INDIA (Cultivated in Nilgiri Hills of Tamil Nadu)-A native of Australia.

*Acacia dodonaeifolia (Pers.) Balb., Cat. Hort. Acad. Taur. 7. 1813; Chakrab. \& M. Gangop. in J. Econ. Taxon. Bot. 20: 630. 1996.

Distribution:-INDIA (Cultivated in Tamil Nadu)-
A native of Australia.

\#Acacia holosericea A. Cunn. ex G. Don, Gen. Syst. 2: 407. 1832; K. M. Matthew, Fl. Palni Hills 1: 405. 1999.

Distribution:-INDIA (Cultivated in Howrah \& Tamil Nadu)-A native of Australia.

*Acacia linifolia (Vent) Willd., Sp. Pl. 4: 1051. 1806; Chakrab. \& M. Gangop. in J. Econ. Taxon. Bot. 20: 630. 1996.

Distribution:-INDIA (Tamil Nadu)-A native of Australia.

*Acacia longissima H. L. Wendl., Comm. Acac. Aphyll.: 45. 1820. Acacia linearis Sim. in Bot. Mag. 47: t. 2156. 1820; B. D. Sharma \& al. in Biol. Mem. 2: 51.1977 .

Distribution:-INDIA (Tamil Nadu)-A native of Australia.

*Acacia longispicata Benth. in Mitch., J. Trop. Austral. 298. 1848; Sanjappa, Legumes Ind. 49. 1992.

Distribution:-INDIA (Cultivated on hill stations of Tamil Nadu)-A native of Australia.

\#Acacia mangium Willd., Sp. Pl. 4:1053.1806.

Distribution:-INDIA (Cultivated in Delhi, Kerala \& Tamil Nadu)-A native of Australia.

\#Acacia prominens A.Cunn. ex G.Don, Gen. Hist. 2: 406. 1832; B.D. Sharma \& al. in Biol. Mem. 2: 51.1977 .

Distribution:-INDIA (Karnataka \& Tamil Nadu)A native of Australia.

*Acacia stricta Willd., Sp. Pl. 4: 1052. 1806; B.D. Sharma \& al. in Biol. Mem. 2: 51. 1977.

Distribution:-INDIA (Tamil Nadu)-A native of Australia.

Aganope agastyamalayana M. B. Viswan., Manik. \& Tangav. in Adansonia 25(2): 206. 2003.

Distribution:-INDIA (Tamil Nadu). 
**Albizia julibrissin Durazz in Mag. Tosc. 3: 11. 1772; B.D. Sharma \& al. in Biol. Mem. 2: 52. 1977.

Distribution:-INDIA (Tamil Nadu, Himalaya, Meghalaya), AFRICA and RUSSIA.

\#Alysicarpus hamosus Edgew., J. Asiat. Soc. Bengal 21: 171. 1853; Arisdason \& P. Daniel in EcoChronicle 2(3): 168. 2007.

Distribution:-INDIA (Andhra Pradesh, Gujrata, Karnataka, Kerala \& Tamil Nadu), Endemic.

**Alysicarpus naikianus Pokle in Reinwardtia 11(4): 285. 1999; Parthipan \& A. Rajendran in Zoo's print 28(2): 28. 2013.

Distribution:-INDIA (Goa, Karnataka, Kerala, Maharashtra \& Tamil Nadu), Endemic.

\#Bauhinia $\times$ blakeana Dunn in J. Bot. 46: 325 . 1908.

Distribution:-INDIA (Cultivated in Tamil Nadu), and CHINA.

*Butea acuminata Wall., Numer. List [Wallich] n. 5443. 1831; Murugan \& Manickam in J. Econ. Taxon. Bot. 25(2): 346. 2001.

Distribution:-INDIA (Tamil Nadu) and SRI LANKA.

**Brownea grandiceps Jacq. in Collectanea 3: 287.1791.

Distribution:-INDIA (Andaman Islands \& Cultivated in Theosophical society, Chennai, Tamil Nadu)-A native of Brazil North, Colombia, Ecuador, Peru, Venezuela.

*Brownea macrophylla Linden ex Mast. in Gard. Chron. 1873: 777. 1873.

Distribution:-INDIA (Cultivated in Theosophical society, Chennai, Tamil Nadu)-A native of Panama \& Peru.

\#Cajanus cajanifolius (Haines) Maesen in Wageningen Agr. Univ. Pap. 85(4): 91. 1986; P. Satyanar. in R.R. Rao, Advan. Leg. Res. India 38. 2002.
Distribution:-INDIA (Andhra Pradesh, Madhya Pradesh, Meghalaya, Odisha \& Tamil Nadu).

*Calliandra calothyrsus Meisn. Linnaea 21: 251. 1848; K. M. Matthew, Fl. Palni Hills 1: 413. 1999.

Distribution:-INDIA (Tamil Nadu)-A native of Central America and Mexico.

\#Calliandra haematocephala Hassk., Retzia 1: 216.1855 .

Distribution:-INDIA (Tamil Nadu)-A native of Central America and Mexico.

Chamaecrista nilgirica (V. Singh) V. Singh in J. Econ. Taxon. Bot. 16(3): 600. 1992. Cassia nilgirica V. Singh in J. Econ. Taxon. Bot. 10(2): 323. 1988.

Distribution:-INDIA (Andhra Pradesh, Kerala \& Tamil Nadu), Endemic.

\#Chamaecrista nomame (Sieb.) Ohashi in J. Jap. Bot. 64(7): 215. 1989; V. Singh, Monogr. Indian subtribe Cassiinae (Caesalpiniac.): 80. 2001.

Distribution:-INDIA (Andhra Pradesh, Assam, Gujarat, Himachal Pradesh, Madhya Pradesh, Maharashtra, Punjab, Rajasthan, Sikkim, Tamil Nadu, West Bengal \& Uttar Pradesh), BHUTAN, CHINA, ETHIOPIA, JAPAN, KOREA, MADAGASCAR, PAKISTAN and TANZANIA.

*Chorizema cordatum Lindl. in Edwards's Bot. Reg. 24: t.10. 1838; B.D. Sharma \& al. in Biol. Mem. 2: 37. 1977.

Distribution:-INDIA (Cultivated in Nilgiris, Tamil Nadu), a native of AUSTRALIA.

\#Crotalaria ferruginea Graham ex Benth. in Hook.'s London J. Bot. 2: 476. 1843; Manickam \& al., Fl. Tirunelveli Hills 1: 274. 2008.

Distribution:-INDIA (Andhra Pradesh \& Tamil Nadu), BHUTAN, INDONESIA, MYANMAR, PHILIPPINES, SRI LANKA and TAIWAN.

*Crotalaria filipes Benth. in Hook. Lond. J. 
Botany 2: 475. 1843; Kottaim. \& Vasud. in J. Bio Sci. Res. 4(1): 1. 2013.

Distribution:-INDIA (Goa, Karnataka, Maharashtra \& Tamil Nadu), Endemic.

\#Crotalaria incana L., Sp. Pl. 716. 1753; Kottaim. in J. Biol. Rec. 1(3): 129. 2016.

Distribution: -INDIA (Karnataka, Kerala \& Tamil Nadu), native to TROP. \& SUBTROPICAL AFRICA.

Crotalaria ramosissima Roxb. var. kanuvayensis Binu Thomas, K. M. P. Kumar \& A. Rajendran in Asian Pacific J. Trop. Biomed. 2(3; suppl.): \$1412. 2012.

Distribution:-INDIA (Tamil Nadu).

Crotalaria ramosissima Roxb. var. ramnadensis A. A. Ansari, Crotalaria India 249. 2008. Crotalaria pellita Bert. ex DC. var. ramnadensis (A.Ansari) Subraman. \& A.K. Pandey in Phytotaxa 183(1): 53. 2014.

Distribution:-INDIA (Tamil Nadu).

Note: Recently, Chauhan and Ansari (2018) submitted a proposal to conserve the name $C$. ramosissima againt $C$. pellitta.

Crotalaria retusa L. var. indica Nampy \& Sibichen in Rheedea 12(2): 143. 2002.

Distribution:-INDIA (Tamil Nadu).

\#Crotalaria trichotoma Bojer in Ann. Sci. Nat. Bot. ser. 2, 4: 265. 1835; Kottaim. \& al. in Indian J. Forest. 38(4): 363. 2015.

Distribution:-INDIA (Jammu-Kashmir, Kerala \& Tamil Nadu), ASIA, AFRICA, AUSTRALIA, CENTRAL \& SOUTH AMERICA.

\#Crotalaria vestita Baker in Hook.f., Fl. Brit. India 2: 67. 1876; N. Balach. et al. in J. Econ. Taxon. Bot. 39(2): 339. 2015.

Distribution:-INDIA (Gujarat, Karnataka, Maharashtra \& Tamil Nadu).

\#Derris heyneana (Wight \& Arn.) Benth. in F.A.W.Miquel, Pl. Jungh.: 252. 1852; K. M.
Matthew, Fl. Palni Hills 1: 315. 1999.

Distribution:-INDIA (Karnataka, Kerala, Maharashtra \& Tamil Nadu) and LAOS.

Dalbergia matthewii Soosairaj, P.Raja \& Britto in Phytotaxa 360(3): 283. 2018.

Distribution:-INDIA (Tamil Nadu).

Derris gamblei Soosairaj, P.Raja \& Dhatchan. in Nordic J. Bot. 35(4): 423. 2017.

Distribution:-INDIA (Tamil Nadu).

Derris matthewii Kottaim. in Webbia 72(1): 97. 2016.

Distribution:-INDIA (Tamil Nadu).

\#Dumbaria glandulosa (Dalz. \& A. Gibson) Prain in J. Asiat. Soc. Bengal 66: 433. 1894; Maesen in Wageningen Agr. Univ. Pap. 98(1): 53. 1998.

Distribution:-INDIA (Andhra Pradesh, Karnataka, Maharashtra \& Tamil Nadu), BANGLADESH, BURMA, NEPAL and THAILAND.

\#Dumbaria punctata Benth., Pl. Jungh. [Miquel] 2: 242. 1852; Maesen in Wageningen Agr. Univ. Pap. 98(1): 76. 1998.

Distribution:-INDIA (Assam, Manipur, Meghalaya, Sikkim, West Bengal \& Tamil Nadu), AUSTRALIA, BANGLADESH, BURMA, CHINA, NEPAL, THAILAND and VIETNAM.

Enterolobium cyclocarpum Griseb., Fl. Brit. W.I. [Grisebach] 226. 1860; B.D. Sharma \& al. in Biol. Mem. 2: 52. 1977.

Distribution:- INDIA (Goa, Gujarat, Karnataka, Kerala, Maharashtra \& Tamil Nadu-A native of MEXICO and TROP. AMERICA.

\#Erythrina fusca Lour., Fl. Cochinch. 427. 1790; Murugan \& al., Recent Advan. Biodiver. India: 41. 2012.

Distribution: -INDIA (Andhra Pradesh, Assam, Orissa, Tamil Nadu \& West Bengal), 
BANGLADESH, BURMA, MALESIA, POLYNESIA and SRI LANKA.

*Genista aetnensis (Biv.) DC., Prodr. [A. P. de Candolle] 2: 150. 1825; B.D. Sharma \& al. in Biol. Mem. 2: 43. 1977.

Distribution:-INDIA (Cultivated in Nilgiris, Tamil $\mathrm{Nadu}$ ), a native of ITALY.

\#Guilandia major (Medik.) Small. in Fl. S.E. U.S.: 591. 1903. Caesalpinia major (Medik.) Dandy \& Exell in J. Bot. 76: 180. 1938; Murugan \& Manickam in J. Bombay Nat. Hist. Soc. 101: 194. 2004.

Distribution:-INDIA (Andhra Pradesh, Karnataka, Kerala, Maharashtra \& Tamil Nadu), MADAGASCAR, TROPICAL \& SUBTROPICAL ASIA to PACIFIC, CARIBBEAN, MEXICO to N. BRAZIL.

\#Indigofera constricta (Thwiates) Trimen, Cat. Ceylon Pl. 23. 1885; Arisdason \& P. Daniel in EcoChronicle 2(3): 168. 2007.

Distribution:- INDIA (Goa, Gujrat, Karnataka, Kerala, Maharashtra \& Tamil Nadu) and SRI LANKA.

Note: Arisdason and Daniel (2007) reported this rare species for the first time in Tamil Nadu from Indira Gandhi Wildlife Sanctaury. Later, Sankar et al. (2012) reported the species from a new locality in Tiruvannamalai District.

Indigofera karaiyarensis Rajakumar, Selvak., S. Murug. \& Chellap. in Indian J. Forestry 34(4): 485. 2011.

Distribution:-INDIA (Tamil Nadu).

Note: Krishnaraj \& Mohanan (2012) have reduced this species as a synonym of Indigofera astragalina DC.

Indigofera kudiraimozhiensis Selvak. \& Rajakumar in India J. Forestry 37(3): 309. 2014.

Distribution:-INDIA (Tamil Nadu).

\#Indigofera zollingeriana Miq., Fl. Ind. Bat. 1:
310. 1855; Kottaim. et al. in J. Bio Sci. Res. 5(1): 128-129. 2015.

Distribution:-INDIA (Andhra Pradesh, Karnataka, Kerala, Tamil Nadu \& West Bengal), CHINA, LAOS, MALESIA, THAILAND and VIETNAM.

\#Kunstleria keralensis C.N. Mohanan \& N.C. Nair, Proc. Indian Acad. Sci. (Pl. Sci.) 90: 207. 1981; Kottaim. \& Vasud. in Elixir Biodiver. 50: 10459. 2012.

Distribution:-INDIA (Karnataka, Kerala \& Tamil Nadu), Endemic.

*Kennedia procurrens Benth. in J. Exped. Trop. Australia [Mitchell] 365. 1848; B.D. Sharma \& al. in Biol. Mem. 2: 44. 1977.

Distribution:-INDIA (Cultivated in Nilgiris, Tamil $\mathrm{Nadu}$ ), a native of Australia.

\#Kennedia rubicunda Vent., Jard. Malmaison 104. 1805; B.D. Sharma \& al. in Biol. Mem. 2: 44. 1977.

Distribution:-INDIA (Cultivated in Nilgiris, Tamil Nadu \& Karnataka), a native of Australia.

*Lamprolobium fruticosum Benth., Fl. Austral. 2: 202. 1864; B.D. Sharma \& al. in Biol. Mem. 2: 44. 1977.

Distribution:-INDIA (Cultivated in Coonoor, Tamil Nadu), a native of Australia.

*Lupinus albus L., Sp. Pl. 2: 721. 1753. Lupinus termis Forssk., Fl. Aegypt.-Arab.: 131. 1775; B.D. Sharma \& al. in Biol. Mem. 2: 44. 1977.

Distribution:-INDIA (Tamil Nadu), a native of Mediterranian region.

*Lupinus pilosus Murray in L. Syst. Veg. 645. 1774; B.D. Sharma \& al. in Biol. Mem. 2: 44. 1977.

Distribution:-INDIA (Tamil Nadu), a native of Mediterranian region.

Millettia pseudoracemosa Thoth. \& S. Ravik. in J. Econ. Taxon. Bot. 21(1): 239. 1997. 
Distribution:-INDIA (Tamil Nadu).

\#Millettia peguensis Ali in Kew Bull. 21(3): 489. 1968.

Distribution:-INDIA (Andhra Pradesh, Karnataka \& Tamil Nadu), BANGLADESH and MYANMAR.

\#Mimosa diplotricha C. Wright ex Sauvalle, Anal. Real. Acad. Ci. Habana 5: 405. 1865; Manickam et al., Fl. Tirunelveli Hills 1: 362. 2008.

Distribution:-INDIA (Naturalized in Kerala \& Tamil Nadu)-Native of TROPICAL AMERICA.

\#Ornithopus perpusillus L., Sp. Pl. 743. 1753; B.D. Sharma \& al. in Biol. Mem. 2: 44. 1977.

Distribution: -INDIA (cultivated in Nilgiris, Tamil Nadu) - Native of Europe.

\#Oxylobium virgatum Benth., Fl. Austal. 2: 22. 1864; B.D. Sharma \& al. in Biol. Mem. 2: 44. 1977.

Distribution: -INDIA (cultivated in Niilgiris, Tamil Nadu) - Native of Australia.

\#Peltophorum africanum Sond. in Linnaea23(1): 35. 1850. Distribution: -INDIA (West Bengal \& cultivated in Theosophical society, Chennai, Tamil Nadu) - Native to AFRICA.

*Philenoptera violacea (Klotzsch) Schrire in Kew Bull. 55(1): 89. 2000.

Distribution: -INDIA (cultivated in Theosophical society, Chennai, Tamil Nadu) - Native to AFRICA.

\#Psoralea aphylla L., Pl. Afr. Rar. 15.; B.D. Sharma \& al. in Biol. Mem. 2: 45. 1977.

Distribution: -INDIA (cultivated in Niilgiris, Tamil Nadu) - Native of SOUTH AFRICA.

\#Psoralea fascicularis DC., Prod. 2: 217. 1825; B.D. Sharma \& al. in Biol. Mem. 2: 45. 1977.

Distribution: -INDIA (cultivated in Niilgiris, Tamil Nadu) - Native of SOUTH AFRICA.

Rhynchosia courtallensis van der Maesen in Rheedea 5: 56. 1995.
Distribution: -INDIA (Andhra Pradesh, Karnataka, Kerala \& Tamil Nadu), Endemic.

Rhynchosia beddomei Baker in Hook.f., Fl. Brit. India 2: 222. 1876; P. Satyanar. in R.R. Rao, Advan. Leg. Res. India 42. 2002.

Distribution: INDIA (Andhra Pradesh, Karnataka \& Tamil Nadu), Endemic.

Rhynchosia ganesanii Kottaim. \& Vasud. in Phytotaxa 201(1): 109. 2015. Rhynchosia fischeri P.Satyanar. \& Thoth. in Bull. Bot. Surv. India 28(14): 241. 1988, nom. illeg., non Harms 1899.

Distribution:-INDIA (Tamil Nadu: Anaimalai).

\#Saraca thaipingensis Cantley ex Prain in J. Asiat. Soc. Bengal, Pt. 2, Nat. Hist. 66(1): 211. 1897.

Distribution: -INDIA (cultivated in Theosophical society, Chennai, Tamil Nadu) - Indo-China to Peninsula Malaysia, Jawa, New Guinea.

*Senegalia lankaensis (Kosterm.) Ragup., Seigler, Ebinger \& Maslin in Phytotaxa 162(3): 175. 2014. Acacia lankaenensis Kosterm. in Ceylon J. Sci. (Biol. Sci.) 13(1): 253. 1979; Manickam \& al., Fl. Tirunelveli Hills 1: 354. 2008.

Distribution:-INDIA (Tamil Nadu) and SRI LANKA.

*Senegalia mellifera (Benth.) Seigler \& Ebinger in Phytologia 92(1): 94. 2010. Acacia mellifera Benth. in London J. Bot. 1: 507. 1842; Chakrab. \& M. Gangop. in J. Econ. Taxon. Bot. 20: 631. 1996.

Distribution:-INDIA (Introduced in Tamil Nadu)A Native of Sudan.

*Senegalia modesta (Wall.) P.J.H.Hurter in D.J.Mabberley, Pl.-Book, ed.3: 1021. 2008. Acacia modesta Wall. Pl. Asiat. Rar. 2: 27. 1831.

Distribution:-INDIA (Cultivated in Alagappa University, Tamil Nadu) and SRI LANKA.

**Senegalia pruinescens (Kurz) Maslin, Seigler \& Ebinger Blumea 58(1): 41. 2013. Acacia pruinescens Kurz in J. Asiat. Soc. Beng. 45: 298. 
1876; Murugan et al. in Rheedea 13: 71. 2003.

Distribution:-INDIA (Arunachal Pradesh, Assam, Megalaya, Mizoram \& Tamil Nadu) and BURMA.

Senegalia tanjorensis (Ragup., Thoth. \& A. Mahad.) Kottaim., comb. nov. Basionym: Acacia tanjorensis Ragup., Thoth. \& A. Mahad. in J. Econ. Taxon. Bot. 14(3): 751. 1990.

Distribution:-INDIA (Tamil Nadu).

Note: Acacia tanjorensis was treated as a distinct species by Kumar and Sane (2003), Roskov et al. (2005) and Ragupathy et al. (2014) but Chakrabarty and Gangopadhyay (1996) have reduced this species under Acacia modesta Wall. without any ample reasons. The present scrutiny of the species in the field and also comparing with the protologue and type specimen of $A$. modesta revealed that the character states of $A$. tanjorensis are diagnostic and warrants unique status. It is not clear why Ragupathy et al. (2014) have combined A. tanjorensis under Vachellia but the character states fall under Sengalia. Hence a new combination is proposed above.

\#Senna italica Mill. subsp. micrantha (Brenan) Lock in Kew Bull. 43(2): 339. 1988; V. Singh, Monogr. Indian subtribe Cassiinae (Caesalpiniac.): 151. 2001.

Distribution:-INDIA (Andhra Pradesh, Karnataka, Kerala, Maharashtra \& Tamil Nadu), ANGOLA, ETHIOPIA, KENYA, TANZANIA and UGANDA.

\#Senna obtusifolia (L.) H. S. Irwin \& Barneby in Mem. New York Bot. Gard. 35(1): 252. 1982; V. Singh, Monogr. Indian subtribe Cassiinae (Caesalpiniac.): 164. 2001.

Distribution:-INDIA (Andhra Pradesh, Gujarat, Himachal Pradesh, Jammu \& Kashmir, Madhya Pradesh, Rajasthan, Tamil Nadu \& Uttar Pradeh)Native of TROPICAL AMERICA, naturalized in tropical regions of the world.

\#Senna pallida (Vahl) H. S. Irwin \& Barneby in Mem. New York Bot. Gard. 35(2): 531. 1982; V. Singh, Monogr. Indian subtribe Cassiinae (Caesalpiniac.): 178. 2001.
Distribution:-INDIA (Cultivated in Andhra Pradesh, Tamil Nadu \& Uttar Pradesh)-A native of SOUTH AMERICA.

Senna septemtrionalis (Viv.) H. S. Irwin \& Barneby var. pubescens (V. Singh) V. Singh, Monogr. Indian subtribe Cassiinae (Caesalpiniac.) 190. 2001. Cassia floribunda Cav. var. pubescens V. Singh in J. Econ. Taxon. Bot. 10(2): 326. 1988.

Distribution:-INDIA (Kerala \& Tamil Nadu).

\#Senna sophera (L.) Roxb. var. purpurea (Roxb. ex Lindl.) V. Singh in J. Econ. Taxon. Bot. 16(3): 600. 1992; V. Singh, Monogr. Indian subtribe Cassiinae (Caesalpiniac.): 203. 2001.

Distribution:-INDIA (Gujarat, Haryana, Kerala, Madhya Pradesh, Maharashtra, Rajasthan, Tamil Nadu, Uttar Pradesh \& West Bengal) and PAKISTAN.

\#Senna spectabilis (DC.) H. S. Irwin \& Barneby in Mem. New York Bot. Gard. 35(2): 603. 1982; P. Satyanar. \& Gnanasek. in Indian J. Forest. 36(2): 243. 2013.

Distribution:-INDIA (Naturalized in Kerala \& Tamil Nadu)-Native of CENTRAL AMERICA.

\#Senna spectabilis (DC.) Irwin \& Barneby var. excelsa (Scharad.) Irwing \& Barneby in Mem. Newyork Bot. Gard. 35(2): 604. 1982; Kottaim. \& al. in Plant Arhives 11(1): 447. 2011.

Distribution:-INDIA (Tamil Nadu).

\#Senna sulfurea (DC. ex Collad.) H. S. Irwin \& Barneby in Mem. New York Bot. Gard. 35(1): 78. 1982; V. Singh, Monogr. Indian subtribe Cassiinae (Caesalpiniac.): 210. 2001.

Distribution:-INDIA (Bihar, Jammu-Kashmir, Himachal Pradesh, Karnataka, Maharashtra, Tamil Nadu \& West Bengal) AUSTRALIA, INDONESIA, MALESIA, MAURITIUS, MYANMAR and WEST INDIES.

Senna uniflora (Mill.) H.S.Irwin \& Barneby in Mem. New York Bot. Gard. 35(1): 258. 1982; Britto in J. Econ. Taxon. Bot. 26(1): 133. 2002. Cassia sericea Sw., Fl. Ind. Occid. 2(1): 724. 1798; 
Murugan \& Manickam in J. Bombay Nat. Hist. Soc. 101: 194. 2004.

Distribution:-INDIA (Andhra Pradesh, Karnataka \& Tamil Nadu), a native to MEXICO and TROP. AMERICA.

\#Sophora tomentosa L., Sp. Pl. 1: 373. 1753.

Distribution:-INDIA (Karnataka \& Tamil Nadu) and CHINA, often cultivated in gardens.

\#Stylosanthes guianensis (Aubl.) Swartz, Svenska, Vetensk. Acad. Handb. 11: 296. 1789; Manickam \& al., Fl. Tirunelveli Hill 1: 321. 2008.

Distribution:-INDIA (Naturalized in Assam, Kerala \& Tamil Nadu), SRI LANKA, TROPICAL AMERICA, ZAMBIA, ZIMBABWE and WEST AFRICA.

**Stylosanthes scabra Vogel in Linnaea 12: 69. 1838; Arul \& al. in J. Basic Appl. Biol. 6(1): 20. 2013.

Distribution: -INDIA (Tamil Nadu) and TROPICAL AMERICA.

*Teline monspessulana (L.) K.H.E. Koch, Dendrologie 1: 30. 1869; Sanjappa, Legumes Ind. 255. 1992.

Distribution:-INDIA (Naturalized in Nilgiri and Palni hills)- Native of Europe.

Tephrosia wynaadensis J.R.Drumm. in Gamble, Fl. Madras 318. 1918; Sanjappa, Legumes Ind. 261. 1992.

Distribution: -INDIA (Kerala \& Tamil Nadu), Endemic.

Vachellia pseudowightii (Thoth.) Kottaim., comb. nov. Basionym: Acacia pseudowightii Thoth. in Rheedea 2(1): 73. 1992. Acacia minutifolia Ragup., A. Mahad. \& Thoth. in Indian J. Forest. 14(1): 65. 1991.

Distribution:-INDIA (Tamil Nadu).

Note: Kumar and Sane (2003) and Chakrabarty and Gangopadhyay (1996) have reduced this species as a synonym of Acacia eburnea (L.f.) Willd. without stating any solid reasons. The present scrutiny of the species in the field and also comparing with the protologue and fresh collections from the type locality of Acacia minutifolia $(=A$. pseudowightii) revealed that the character states are diagnostic and warrants unique status.

* Vachellia robusta (Burch.) Kyal. \& Boatwr. in Bot. J. Linn. Soc. 172(4): 516. 2013 Acacia robusta Burch., Trav. 2: 442. 1824; B.D. Sharma \& al. in Biol. Mem. 2: 51.1977.

Distribution:-INDIA (Tamil Nadu)-Native of Africa.

Note: The species is not surviving at present (Chakrabarty \& Gangopadhyay, 1996).

\#Vigna pilosa (Roxb.) Baker in Hook.f., Fl. Brit. India 2: 207. 1876; Betty \& V.S.Ramach. in Photon 113: 357. 2014.

Distribution:-INDIA (Andhra Pradesh, Karnataka, Odisha \& Uttar Pradesh), Endemic.

**Vigna subramanianus (Babu ex Raizada) Raizada in Indian J. Forest. 3(2): 133. 1980; K. M. Matthew, Fl. Palni Hills 1: 376. 1999.

Distribution:-INDIA (Madhya Pradesh, Punjab, Tamil Nadu, Uttar Pradesh), Endemic.

Xylia xylocarpa (Roxb.) Taub., Bot. Centralbl. 47: 395. 1891; B.D. Sharma \& al. in Biol. Mem. 2: 52. 1977 .

Distribution:-INDIA (Andhra Pradesh, Karnataka, Kerala, Odisha \& Tamil Nadu) and Malesia.

\#Zornia quilonensis Ravi in J. Bombay Nat. Hist. Soc. 66:489.1969; Sanjappa, Legumes Ind. 280. 1992.

Distribution:-INDIA (Kerala, Tamil Nadu \& West Bengal), Endemic.

Note: Krishnaraj \& Mohanan (2012) have reduced this species as a variety under Zornia diphylla (L.) Pers. 


\section{Conflict of interest statement}

Author declares that there is no conflict of interest.

\section{Acknowledgements}

I am grateful to Dr. N. Vasudevan for constant encouragement and critical suggestions throughout the doctoral course. I wish to thank retd. Dr. G.V.S. Murthy, Scientist 'G', Botanical Survey of India, Southern Regional Centre for granting permission to consult the herbarium and library. I also extend my sincere thanks to Dr. A. K. Pandey (Delhi University), Dr. W. Arisdason (CNH, Kolkatta) and Dr. M. V. Krishnaraj (Kerala) for providing literature.

\section{References}

Ansari, A. A., 2008. Crotalaria L. in India. Bishen Singh Mahendra Pal Singh, Dehra Dun.

Arisdason, W., Daniel, P., 2007. Additions to the flora of Tamil Nadu. Eco-Chronicle 2(3), 159161.

Arul, A.A.A., Karuppusamy, S., Jeeva, S. 2013. Stylosanthes scabra Vogel (Fabaceae) - an addition to the flora of Southern peninsular India. J. Basic Appl. Biol. 6(1), 19-21.

Baker, J. G., 1876. Leguminosae. In: Hooker, J. D. (ed.) The Flora of British India Vol: 2. L. Reeve \& Co., Henrietta Street, London.

Balachandran, N., Ravikumar, K., Datchanamoorthy, N., Gokul, S., Tiwari, U., Begum, S. N. 2015. Some interesting additions to the flora of Tamil Nadu. J. Econ. Taxon. Bot. 39(2), 338-341.

Bentham, G., 1843. Enumeration of Leguminosae, indigenous to Southern Asia and Central and Southern Africa. London J. Bot. 2, 423-483.

Betty, T., Ramachandran, V. S., 2014. Additions to the Flora of Tamil Nadu, Southern India. Photon. 113, 355-359.

Britto, S. J., 2002. Senna uniflora (Mill.) H.S. Irwin \& R.C.Barneby - A new plant record for Tamil Nadu. J. Econ. Taxon. Bot. 26(1), 133135 .

Burman, N. L., 1786. Flora Indica: Cui Accedit Series Zoophytorum Indicorum nec non Prodromus Florae Capensis. Cornelius Haak, Leiden \& Johannes Schreuder, Amsterdam.

Chakrabarty, T., Gangopaghyay, M. 1996. The genus Acacia P. Miller (Leguminosae: Mimosoideae) in Indian subcontinent. J. Econ. Taxon. Bot. 20(3), 599-633.

Chakrabarty, T., Maina, V., 2015. A note on the occurrence of Acacia colei (Leguminosae: Mimosoideae) in India. J. Econ. Taxon. Bot. 39(1), 194-196.

Chauhan, V., Ansari, A. A., 2018. Proposal to conserve the name Crotalaria ramosissima against $C$. pellita (Fabaceae). Taxon 67(4): 818-819.

De Candolle, A. P., 1825. Leguminosae. Prodromous systematis naturalis. Regni Vegetabilis. 2, 93-524.

Kottaimuthu, R., 2016. First record of Crotalaria incana L. (Fabaceae) in Tamil Nadu. J. Biol. Rec. 1(3), 128-130.

Kottaimuthu, R., Suresh, K., Kumuthakalavalli, R., 2011. Additions to the Legumes of Eastern Ghats, India. Plant Arch. 11(1), 447-448.

Kottaimuthu, R., Vasudevan, N., 2012. New plant records for Tamil Nadu State, India. Elixir Bio Diver. 50, 10459-10461.

Kottaimuthu, R., Vasudevan, N., 2013. Occurrence of Crotalaria filipes Benth. (Fabaceae) in Tamil Nadu. J. Bio Sci. Res. 4(1), 1-3.

Kottaimuthu, R., Vasudevan, N., 2015. Rhynchosia ganesanii, a new name for Rhynchosia fischeri P. Satyanar. \& Thoth. (Leguminosae: Papilionoideae), from India. Phytotaxa. 201(1), 109-110.

Kottaimuthu, R., Vasudevan, N., 2017. A new species of Derris Lour. (Fabaceae: Papilionoideae) from Tamil Nadu, India. Webbia. 72(1), 97-100.

Kottaimuthu, R., Vasudevan, N., Saravanan, A., 2015. Crotalaria trichotoma Bojer (Fabaceae): A new record for Tamil Nadu, India. Indian J. Forest. 38(4), 363-364.

Kottaimuthu, R., Vasudevan, N., Saravanan, A., 2015. Indigofera zollingeriana Miq. (Fabaceae: Indigoferae), a new record for Tamil Nadu, India. J. Bio Sci. Res. 5(1), 128-131.

Krishnaraj, M. V., Mohanan, N., 2012. Notes on the identity and status of two legumes (Fabaceae: Papilionoideae) from India. Phytotaxa. 66, 13-20.

Kumar, S., Sane, P. V., 2003. Legumes of South Asia: A Checklist. Royal Botanic Gardens, Kew,

Lamarck, J.B.A.P., 1785 \& 1786. Encyclopédie Méthodique, Botanique. 1 \& 2. Paris.

Lewis, G., Schrire, B., Mackinder, B., Lock, M., 
2005. Legumes of the World. The Royal Botanic Gardens, Kew.

Linnaeus, C., 1753. Species Plantarum. L. Salvii, Stockholm.

Linnaeus, C., 1754. Genera Plantarum. L. Salvii, Stockholm.

Manickam, V. S., Murugan, C., Jothi, G. J., Sundaresan, V., 2008. Flora of Tirunelveli Hills: Southern Western Ghats. Vol. I. Polypetalae. Bishen Singh Mahendra Pal Singh, Dehra Dun.

Manilal, K. S., 2003. Van Rheede's Hortus Malabaricus. Annotated English Edition. (12 Vols.) University of Kerala. Thiruvananthapuram.

Matthew, K. M., 1999. Flora of the Palni hills, South India. Part: I-III. St. Joseph College, The Rapinat Herbarium, Tiruchirapalli.

Murugan, C., Manickam, V. S., 2001. Two distributional records for India. J. Econ. Taxon. Bot. 25(2), 346-349.

Murugan, C., Manickam, V. S., 2004. Two distributional records of Caesalpiniaceae for Tamil Nadu. J. Bombay Nat. Hist. Soc. 101, 194.

Murugan, C., Murthy, G. V. S., Sudhakar, J. V., 2012. Seven interesting plants from South India. In: Raghunathan, C., Sivaperuman, C., Venkataraman, S., (Eds.), Recent Advances in Biodiversity of India. Zoological Survey of India, Kolkatta.

Nicolson, D. H., Suresh, C. R., Manilal, K. S., 1988. An Interpretation of Van Rheede's Hortus Malabaricus. Regnum Vegetabile Vol. 119. Germany.

Parthipan, M., Rajendran, A., 2013. Occurrence of an endemic taxon Alysicarpus naikianus Porkle in the Eastern Ghats, India. Zoo's Print. 28(2), 28-29.

Ragupathy, S., Mahadevan, A., Thothathri, K. 1991. Acacia minutifolia Ragu. et al. (Leguminosae : Mimosoideae): a new species from the Coromandel coast of Thanjavur district, Tamil Nadu. Indian J. Forest. 14(1), 65-66.

Ragupathy, S., Seigler, D., Ebinger, J.E., Maslin, B.R., 2014. New combinations in Vachellia and Senegalia (Leguminosae: Minosoideae) for south and west Asia. Phytotaxa. 162(3), 174-180.

Ragupathy, S., Thothathri, K., Mahadevan, A., 1990. A new species of Acacia (Mimosaceae) from Thanjavur district, Tamil Nadu, India. J. Econ. Taxon. Bot. 14(3), 751-752.
Raja, P., Soosairaj, S., Datchanamoorthy, N., Tagore, T. K., 2017. Derris gamblei sp. nov. (Fabaceae) from Tamil Nadu, India. Nordic J. Bot. 35(4), 423-425.

Rajakumar, T. J. S., Selvakumari, R., Murugesan, S., Chellaperumal, N., 2011. Indigofera karaiyarensis, a new species of Fabaceae from Thirunelveli district, Tamil Nadu, India. Indian J. Forest. 34, 485-486.

Roxburg, W., 1820-1832. Flora Indica. Vol. I-III. Serampore.

Sanderson, M.J., Wojciechowski, M.F., 1996. Diversification rates in a temperate legume clade: Are there "so many species" of Astragalus (Fabaceae)? Amer. J. Bot. 83, 1488-1502.

Sanjappa, M., 1992. Legumes of India. Mahendra Pal Singh, Dehra Dun.

Sanjappa, M., 2001. Leguminosae. In: Singh, N. P., Singh, D. K., (Ed.), Floristic Diversity and Conservation Strategies. Botanical Survey of India.

Sankar, R. V., Ravikumar, K., Ravichandran, P., 2012. Plant Resources of Tiruvannamalai District, Tamil Nadu, India. Bishen Singh Mahendra Pal Singh, Dehra Dun.

Satyanarayana, P., Gnanasekaran, G., 2013. An exotic tree species Senna spectabilis (DC.) Irwin \& Barneby (Caesalpiniaceae): Naturalized in Tamil Nadu and Kerala. Indian J. Forest. 36(2), 243-246.

Satyanarayana, P., Thothathri, K., 1988. Three new species of Rhynchosia Lour. (Fabaceae) from India. Bull. Bot. Surv. India 28(1-4), 241-245.

Schrire, B. D., Lavin, M., Lewis, G. P., 2005. Global distribution patterns of the Leguminosae: Insights from recent phylogenies. Biol. Skr. 55, $375-422$.

Selvakumari, R., Rajakumar, T.J.S., 2014. Indigofera kudiraimozhiensis-A new species of Fabaceae from Kudiraimozhi Their, Thoothukudi District, Tamil Nadu, India. Indian J. Forest. 37(3), 309-310.

Sharma, B. D., Shetty, B. V., Vajravelu, E., Kumari, G. R., Vivekananthan, K., Chandrabose, M., Swaminathan, M. S., Chandrasekaran, R., Subba Rao, G. V., Ellis, J. L., Rathakrishnan, N. C., Karthikeyan, S., Chandrasekaran, V., Srinivasan, S. R., 1977. Flora of Nilgiris, Tamil Nadu. Biol. Mem. 2(1\&2), 1-186.

Sibichen, M. T., Nampy, S., Nisha, P., 2002. Crotalaria retusa L. var. indica Nampy \& 
Sibichen (Papilionaceae) - a new variety from India. Rheedea. 12, 143-146.

Singh, V., 1988. The genus Cassia L. (Caesalpiniaceae): Some new taxa and combinations from J. Econ. Taxon. Bot. 10(2), 321-327.

Singh, V., 2001. Monograph on Indian subtribe Cassiinae (Caesalpiniaceae). Scientific Publishers, Jodhpur, India.

Subramaniam, S., Pandey, A. K., 2014. Reinstatement of Crotalaria pellita (Leguminosae, Papilionoideae) and a new combination for its variety. Phytotaxa. 183(1), 51-55.

Taubert, P., 1894. Leguminosae. In: Engler, A. \& K. Prantl (Eds.), Die Naturlichen Pflanzenfamilian. Berlin.

Thomas, B., Kumar, K. M. P., George, S., Rajendran, A., Balachandran, I., 2012. A new variety of Crotalaria ramosissima (Fabaceae) from Tamil Nadu. Asian Pac. J. Trop. Biomed. 2012, 1-3.

Thothathri, K., 1992. Nomenclatural note on Acacia minutifolia Raghu et al. from India. Rheedea. 2(1), 73.

Thothathri, K., Das, D. N., 1991. A new species of Tephrosia Pers. From Kerala. Rheedea 1(1-2): 57-58.

Thothathri, K., Ravikumar, S., 1997. A new species of Millettia (Leguminosae) from the Annamalai Hills, Tamilnadu. J. Econ. Taxon. Bot. 21(1),
239-242.

van der Maesen, L. J. G., 1998. Revision of the genus Dunbaria Wight et Arn. (LeguminosaePapilionoideae). Wageningen Agric. Univ. Pap. 98(1), 1-109.

van der Maesen, L. J. G., 1995. Rhynchosia courtallensis van der Maesen, a new name for the South Indian Dunbaria latifolia Wt. \& Arn. (Leguminosae - Papilionoideae). Rheedea. 5(1), 54-59.

Viswanathan, M. B., Manikandan, U., Tangavelou, A. C., 2003. A new species of Aganope (Fabaceae) from the Southern Western Ghats, Peninsular India. Adansonia. 25(2), 205-210.

Wallich, N., 1820. Description of some rare Indian plants. Asiat. Res. 13, 369-415.

Wight, R., Arnott, G. A., 1834. Prodromus florae Peninsulae Indiae Orientalis. Parburry, Allen \& Co., London.

Willdenow, C. L., 1802. Species Plantarum, ed., 3(2). Impensis G.C. Nauk, Berolini [Berlin].

Yahara, T., Javadi, F., Onoda, Y., Queiroz, L. P. de, Faith, D., Prado, D. E., Akasaka, M., Kadoya, T., Ishihama, F., Davies, S., Slik, J. W. F., Yi, T., Ma, K., Bin, C., Darnaedi, D., Pennington, R. T., Tuda, M., Shimada, M., Ito, M., Egan, A. N., Buerki, S., Raes, N., Kajita, T., Vatanparast, M., Mimura, M., Tachida, H., Iwasa, Y., Smith, G. F., Victor, J. E., Nkonki, T., 2013. Global legume diversity assessment: Concepts, key indicators, and strategies. Taxon. 62, 249-266.

\section{How to cite this article:}

Kottaimuthu, R., 2019. Supplement to the legumes of Tamil Nadu, India. Int. J. Curr. Res. Biosci. Plant Biol. 6(3), 31-41. doi: https://doi.org/10.20546/ijcrbp.2019.603.005 